\title{
Learning Strategies Using Augmented Reality Technology in Education: Meta-Analysis
}

\author{
Mohd Fadzil Abdul Hanid ${ }^{1, *}$, Mohd. Nihra Haruzuan Mohamad Said ${ }^{2}$, Noraffandy Yahaya ${ }^{2}$ \\ ${ }^{1}$ Johor Bahru District Education Office, Johor, Malaysia \\ ${ }^{2}$ Department of Educational Sciences, Mathematics and Creative Multimedia, School of Education, Faculty of Social Sciences and \\ Humanities, Universiti Teknologi Malaysia, Malaysia
}

Received January 22, 2020; Revised April 1, 2020; Accepted April 21, 2020

Copyright $\odot 2020$ by authors, all rights reserved. Authors agree that this article remains permanently open access under the terms of the Creative Commons Attribution License 4.0 International License

\begin{abstract}
The learning environment is changing rapidly with the advent of the Industrial Revolution 4.0. One of the trending technologies in education is Augmented Reality. The Augmented Reality technology allows users to interact with virtual objects that are integrated into the real world and appear in the same space in real-time. The purpose of this meta-analysis is to identify the types of learning strategies that have been implemented using the Augmented Reality technology. The research methodology is based on a systematic literature search in online databases, namely, Scopus, Web of Science, Science Direct, Taylor Francis, and Springer. Keywords used in the search include Augmented Reality in education, learning strategies, integration strategies, as well as Augmented Reality teaching and learning. The results of this meta-analysis reveal that interactive learning, game-based learning, collaborative learning, and experiential learning are the dominant strategies in education that use Augmented Reality. Such findings will provide educators with guidance on the learning strategies that use Augmented Reality and its potential in education, which will subsequently lead to further research on how learning strategies using the Augmented Reality technology can be implemented in teaching and learning effectively.
\end{abstract}

Keywords Augmented Reality, Learning Strategies, Education, Integration Strategies

\section{Introduction}

The Augmented Reality (AR) technology has been experiencing growth in tandem with various types of hardware, especially with the development of various types of gadgets and smart device applications. The AR technology can create illusions in the real world through a virtual digital layer in order to improve the spatial visualisation skill. This feature can be utilised and has the potential to be used in the education field [1]. AR can be defined as the technology used to combine virtual world objects into the real world, which then appear together in the same world space [2]. AR is currently becoming a trend in the education field. Research showed significant results where the students that used the AR technology could improve their level of motivation as well as possessing high levels of confidence and satisfaction in using AR-based mobile devices in learning [3]. These findings are consistent with the study by [4] that stated that teaching by using the AR application could attract the attention of students and enhance their learning motivation.

\section{Learning Strategies Using the Augmented Reality (AR) Technology}

Learning strategies have been given various definitions by different authors. [5] stated that it means the layout of cognitive operations aimed at guiding students to understand problems until they can find the answers. [6] regarded learning strategies as the procedures and techniques used with planning that have objectives and contextually to process new information to try achieving meaningful learning. Creating a good learning process requires a variety of learning strategies that are appropriate for the learning condition or situation. According to the study by [7], some previous studies show that the results of cognitive and spatial learning using AR are influenced by the learning strategies implemented. Learning strategies using the AR technology are important to create a learning environment that can provide students with new methods for interactions by using different devices along with 
collaboration opportunities among students and also between students and teachers which can potentially enhance their learning motivation [8].

\section{Research Questions}

This meta-analysis is a structured methodology to synthesise the existing studies in order to identify the dominant learning strategies to promote the integration of AR in different levels of education. Specifically, this paper is aimed at answering the following research questions:

(1) Which learning strategies use Augmented Reality (AR)?

(2) At which levels of education (primary, secondary, or tertiary) do learning strategies use Augmented Reality (AR)?

\section{Methodology}

In this section, the methods used to retrieve the articles related to learning strategies that use the AR technology are discussed. The researchers employed a method called
PRISMA, used to carry out the study using the methods of systematic review, eligibility and exclusion criteria, steps of the review process (identification, screening, eligibility), and data extraction and analysis. The review was guided by the PRISMA Statement (Preferred Reporting Items for Systematic reviews and Meta-Analyses). PRISMA offers three unique advantages, which are 1) it defines clear research questions that permits systematic research, 2) it identifies the inclusion and exclusion criteria, and 3) it attempts to examine a large database of scientific literature in a defined time.

This study is aimed at identifying the learning strategies that use AR. The following keywords were used in the database search: augmented reality, learning strategy, and learning integration. The search was conducted in Scopus, Web of Science, Science Direct, Taylor Francis, and Springer. The search produced 1167 hits, but only 17 were considered relevant to the study based on the following criteria: (1) the study should state that the learning strategy uses AR, (2) the study was published between the year 2015 and 2019, and (3) the study should have empirical data. After analysing using a systematic literature review based on the method adapted from [9], this study was summarised as shown in Table 1.

Table 1. Search strings used for the systematic review process

\begin{tabular}{cl}
\hline Database & \multicolumn{1}{c}{ Keywords Used } \\
\hline Scopus & "Augmented Reality" AND ("Learn* Strateg*” OR "Teach* Strateg*”) \\
\hline $\begin{array}{c}\text { Web of } \\
\text { Science }\end{array}$ & (Augmented Reality) AND TOPIC: (Learn* Strateg*) NOT TOPIC: (Virtual Reality) \\
\hline $\begin{array}{c}\text { Science } \\
\text { Direct }\end{array}$ & (“Augmented Reality") AND Learning Strategies AND Integration Strategies AND NOT "Virtual Reality" \\
\hline $\begin{array}{c}\text { Taylor } \\
\text { Francis }\end{array}$ & $\begin{array}{l}\text { NOll: "augmented reality"] AND [All: learning] AND [All: strategies] AND [All: integration] AND [All: strategies] AND } \\
\text { Computer Science] AND [All Subjects: Mathematics \& Statistics] }\end{array}$ \\
\hline Springer & $\begin{array}{l}\text { Augmented AND Reality AND Learning AND Strategies AND Integration AND Strategies AND NOT ("Virtual AND } \\
\text { Reality") }\end{array}$ \\
\hline
\end{tabular}


Records identified through Scopus searching ( $n=698$ )
Records identified through WoS searching ( $n=105$ )
Additional records identified through other sources - Science Direct, Taylor Francis, Springer $(n=64+54+261=379)$

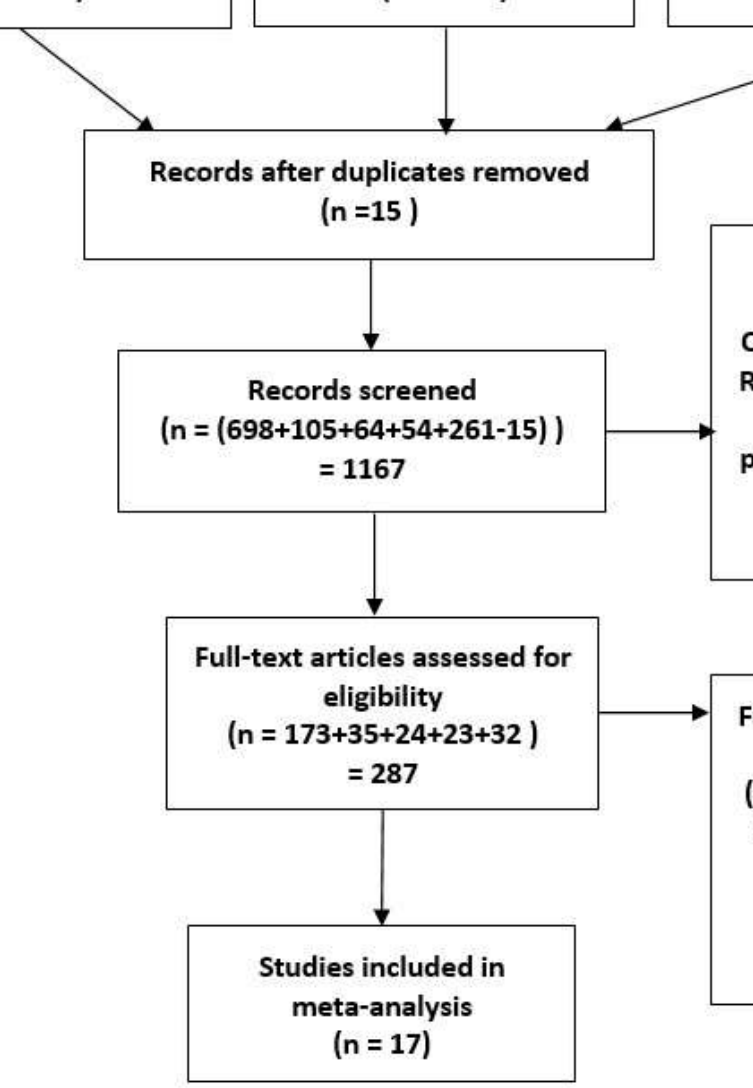

Full-text articles excluded, with reasons

( $n=270$ ) (excluded due to did not based on empirical data, did not focus on strategy learning using Augmented Reality)

Figure1. The flow diagram of the study. (Adapted from Moher et al., 2009) 
Table 2. Findings of the study

\begin{tabular}{|c|c|c|c|}
\hline Study & Research Purpose(s) & $\begin{array}{l}\text { Learning } \\
\text { Strategies }\end{array}$ & Level / Age \\
\hline$[10]$ & $\begin{array}{l}\text { To explore whether integrating AR techniques could support a software editing course } \\
\text { and to examine the different learning effects on students. }\end{array}$ & $\begin{array}{c}\text { Blended } \\
\text { Learning }\end{array}$ & Tertiary \\
\hline$[11]$ & $\begin{array}{l}\text { To determine the feasibility of using AR for applied mathematics learning in primary } \\
\text { education for students with special needs (SEN). }\end{array}$ & $\begin{array}{l}\text { Collaborative } \\
\text { Learning }\end{array}$ & $\begin{array}{l}\text { Primary Age } \\
\quad(6-12)\end{array}$ \\
\hline [12] & $\begin{array}{l}\text { To focus on the standard nonverbal social cues to teach children with Autism Spectrum } \\
\text { Disorder (ASD). }\end{array}$ & $\begin{array}{c}\text { Interactive } \\
\text { Learning }\end{array}$ & $\begin{array}{c}\text { Primary Age } \\
(8-9)\end{array}$ \\
\hline [13] & $\begin{array}{l}\text { To integrate AR technology running on tablet PCs (TPCs), either in the classroom or in a } \\
\text { u-learning environment. }\end{array}$ & $\begin{array}{c}\text { Ubiquitous-lear } \\
\text { ning } \\
\text { (u-learning) }\end{array}$ & $\begin{array}{l}\text { Secondary } \\
\text { Age (13) }\end{array}$ \\
\hline$[14]$ & $\begin{array}{l}\text { To investigate the effects of the argumentation-based science learning approach on } \\
\text { students' academic achievements. }\end{array}$ & $\begin{array}{l}\text { Argumentation- } \\
\text { based Science } \\
\text { Learning }\end{array}$ & $\begin{array}{l}\text { Secondary } \\
\text { Age }(12-13)\end{array}$ \\
\hline$[15]$ & To focus on the emotional impact of integrating the AR technology into learning. & $\begin{array}{c}\text { Experiential } \\
\text { Learning }\end{array}$ & $\begin{array}{c}\text { Secondary } \\
\text { Age }(11-13)\end{array}$ \\
\hline [16] & $\begin{array}{l}\text { This study developed and compared two AR learning systems for third-grade students to } \\
\text { learn English vocabulary in situated surroundings. }\end{array}$ & $\begin{array}{l}\text { Game-based } \\
\text { Learning }\end{array}$ & $\begin{array}{c}\text { Primary Age } \\
(8-9)\end{array}$ \\
\hline [17] & $\begin{array}{l}\text { This study explored the process of students' co-construction of knowledge in a digital } \\
\text { game-based learning environment using collaborative AR-based mathematics game. }\end{array}$ & $\begin{array}{l}\text { Collaborative } \\
\text { Learning \& } \\
\text { Game-based } \\
\text { Learning }\end{array}$ & $\begin{array}{l}\text { Secondary } \\
(11-12)\end{array}$ \\
\hline [18] & $\begin{array}{l}\text { This study investigated the effects of Problem-based Learning (PBL) assisted with AR on } \\
\text { learning achievement and attitude. }\end{array}$ & $\begin{array}{l}\text { Problem-based } \\
\text { Learning }\end{array}$ & $\begin{array}{l}\text { Secondary } \\
\text { Age }(12-13)\end{array}$ \\
\hline [19] & To present a general technical, creative design teaching scheme that includes AR. & $\begin{array}{l}\text { Creative } \\
\text { Design } \\
\text { Learning } \\
\text { Motivation }\end{array}$ & Tertiary \\
\hline [20] & $\begin{array}{l}\text { To describe the development and evaluation of an AR system for teaching Euclidean } \\
\text { vectors in physics and mathematics. }\end{array}$ & $\begin{array}{c}\text { Interactive } \\
\text { Learning }\end{array}$ & $\begin{array}{c}\text { Tertiary Age } \\
(18-22)\end{array}$ \\
\hline [21] & $\begin{array}{l}\text { To determine the scope and potential uses of AR in the education of information } \\
\text { professionals. }\end{array}$ & $\begin{array}{c}\text { Learning } \\
\text { Environment }\end{array}$ & Tertiary \\
\hline [22] & $\begin{array}{l}\text { To investigate whether mobile AR affected learning, motivation, and math anxiety } \\
\text { differently between students with high and low anxiety. }\end{array}$ & Mobile learning & $\begin{array}{c}\text { Secondary } \\
\text { Age } \\
(11-12) \\
\end{array}$ \\
\hline$[23]$ & To integrate AR with concept maps to form a concept-mapped AR (CMAR) scaffold. & $\begin{array}{l}\text { Interactive } \\
\text { Learning }\end{array}$ & $\begin{array}{c}\text { Secondary } \\
\text { Age }(10-11)\end{array}$ \\
\hline [24] & $\begin{array}{l}\text { To analyse the effect of Pokémon GO on cognitive performance and emotional } \\
\text { intelligence. }\end{array}$ & $\begin{array}{l}\text { Interactive } \\
\text { Learning }\end{array}$ & $\begin{array}{c}\text { Secondary } \\
\text { Age }(12-15)\end{array}$ \\
\hline [25] & $\begin{array}{l}\text { To explore if new mobile AR technologies have the potential to enhance the learning of } \\
\text { clinical skills in the lab. }\end{array}$ & $\begin{array}{l}\text { Experiential } \\
\text { Learning }\end{array}$ & Tertiary \\
\hline [26] & $\begin{array}{l}\text { To demonstrate the influence of AR used as a tool for educational content on student } \\
\text { concentration }\end{array}$ & $\begin{array}{l}\text { Interaction } \\
\text { Learning }\end{array}$ & Tertiary \\
\hline
\end{tabular}

\section{Results and Discussion}

Based on the meta-analysis in Table 2, four key learning strategies that use Augmented Reality (AR) have been identified: interactive learning, game-based learning, collaborative learning, and experiential learning. Among the four types of learning strategies, interactive learning is the most reported in this meta-analysis review. According to [27], interactive learning is a learning process where students use cognitive and metacognitive strategies to interact with the information presented in learning. This statement is supported by [28], who explained that previous studies have proven that the interactive learning strategy is better in terms of creating fun and exciting interactions that boost student motivation.

Next, game-based learning strategy refers to the use of certain game principles and their implementation in learning to involve the users [29]. According to [29], game-based learning can be used in various educational methods across disciplines and has been proven effective in the classroom when designed with the learning principles, which will enable students to increase their motivation, involvement, and learning. The study by [30] reveals that learning that combines $\mathrm{AR}$ and game-based learning strategy has been proven useful in learning in the aspects of motivation and interest in the learning activities conducted.

Meanwhile, according to [31], collaborative learning strategy is defined as a situation where two or more people learn or try to learn something together. Collaborative learning strategy is an important educational practice that can be an effective approach when certain cognitive and social processes are supported [32]. [33] asserted that the benefits of collaborative learning strategy are not limited to improvements in performance only but more importantly 
in enhancing the processes in learning itself.

The fourth most reported learning strategy in this meta-analysis study is experiential learning, which refers to a learning method that uses experience as a medium for learning [34]. [35] stated that experiential learning occurs when individuals are involved in cognitive and effective aspects and act to process knowledge, skills, and attitude in learning situations, which is categorised as active engagement at a high level. This statement was proven in a study by [36] that implemented experience-based learning (Experiential Learning) in developing an innovative learning model that showed improvements in creative thinking, which is in line with the opinion of [37] who stated that experience-based learning (Experiential Learning) allows students to actively build their knowledge in learning. Other learning strategies found in this study include blended learning, ubiquitous-learning (u-learning), argumentation-based science learning, mobile learning, and interaction learning. These learning strategies can provide a new dimension in technology integration, particularly AR, which is consistent with today's rapidly changing learning environment based on the 21 st-century learning skills with the STEM elements.

\section{Future Suggestions}

There is growing interest in integrating learning strategies with the Augmented Reality (AR) technology in education. Thus, prior to using the AR technology in the learning environment, researchers are encouraged to plan well-structured teaching and learning components encompassing (1) students' needs, (2) learning objectives, (3) the forms of support such as equipment, and (4) the types of learning strategies that suit students' needs. Also, questions have been raised of whether AR technology can improve the learning process in terms of thinking through problem solving methods.

\section{Conclusion}

In conclusion, four types of learning strategies that use Augmented Reality are typical in the selection of strategies for the learning process based on meta-analysis, and these strategies are interactive learning, game-based learning, collaborative learning, and experiential learning. Therefore, the technologies used in particular Augmented Reality must be integrated with appropriate learning strategies for the purpose of making an impact on improving the quality of the learning process. The selection of appropriate learning strategies can influence the success and effectiveness of the technology support used, such as Augmented Reality in education.

\section{REFERENCES}

[1] Rezende WJ, Albuquerque ES, Ambrosio AP. Use of Augmented Reality to Support Education - Creating a Mobile E-learning Tool and using it with an Inquiry-based Approach. 2017;1: 100-107.

[2] Akçayır M, Akçayır G. Advantages and challenges associated with augmented reality for education: A systematic review of the literature. Educ Res Rev. 2017;20: $1-11$.

[3] Cai S, Wang X, Chiang FK. A case study of Augmented Reality simulation system application in a chemistry course. Comput Human Behav. 2014;37: 31-40.

[4] Cai S, Chiang FK, Wang X. Using the Augmented Reality 3D Technique for a Convex Imaging Experiment in a Physics Course. Int J Eng Educ. 2013;29: 856-865.

[5] Gagné RM. The conditions of learning and theory of instruction. 4th ed. New York : Holt, Rinehart and Winston; 1985.

[6] Muelas A, Navarro E. Learning Strategies and Academic Achievement. Procedia - Soc Behav Sci. 2015;165: 217221.

[7] Buchori A, Setyosari P, Dasna IW, Ulfa S, Degeng INS, Sa'dijah C. Effectiveness of Direct Instruction Learning Strategy Assisted by Mobile Augmented Reality and Achievement Motivation on Students Cognitive Learning Results. Asian Soc Sci. 2017;13: 137.

[8] Sampaio D, Almeida P. Pedagogical Strategies for the Integration of Augmented Reality in ICT Teaching and Learning Processes. Procedia Comput Sci. 2016;100: 894899.

[9] Moher D, Liberati A, Tetzlaff J, Altman DG, Grp P. Preferred Reporting Items for Systematic Reviews and Meta-Analyses: The PRISMA Statement (Reprinted from Annals of Internal Medicine). Phys Ther. 2009;89: 873880 .

[10] Wang YH. Using augmented reality to support a software editing course for college students. J Comput Assist Learn. 2017;33: 532-546.

[11] Cascales-Martínez A, Martínez-Segura MJ, Pérez-López D, Contero M. Using an augmented reality enhanced tabletop system to promote learning of mathematics: A case study with students with special educational needs. Eurasia J Math Sci Technol Educ. 2017;13: 355-380.

[12] Lee IJ, Chen CH, Wang CP, Chung CH. Augmented Reality Plus Concept Map Technique to Teach Children with ASD to Use Social Cues When Meeting and Greeting. Asia-Pacific Educ Res. 2018;27: 227-243.

[13] Huang YM, Lin PH. Evaluating students' learning achievement and flow experience with tablet PCs based on AR and tangible technology in u-learning. Libr Hi Tech. 2017;35: 602-614.

[14] Akbaş Y, Şahin IF, Meral E. Implementing argumentation-based science learning approach in social studies: Academic achievement and students' views. Rev Int Geogr Educ Online. 2019;9: 209-245. 
[15] Huang TC, Chen CC, Chou YW. Animating eco-education: To see, feel, and discover in an augmented reality-based experiential learning environment. Comput Educ. 2016;96: 72-82.

[16] Hsu TC. Effects of gender and different augmented reality learning systems on English vocabulary learning of elementary school students. Univers Access Inf Soc. 2019;18: 315-325.

[17] Cheng YW, Wang Y, Cheng IL, Chen NS. An in-depth analysis of the interaction transitions in a collaborative Augmented Reality-based mathematic game. Interact Learn Environ. 2019;27: 782-796.

[18] Fidan M, Tuncel M. Integrating augmented reality into problem based learning: The effects on learning achievement and attitude in physics education. Computers \& Education. Elsevier Ltd; 2019.

[19] Wei X, Weng D, Liu Y, Wang Y. Teaching based on augmented reality for a technical creative design course. Comput Educ. 2015;81: 221-234.

[20] Martin-Gonzalez A, Chi-Poot A, Uc-Cetina V. Usability evaluation of an augmented reality system for teaching Euclidean vectors. Innov Educ Teach Int. 2016;53: 627636.

[21] Wójcik M. Potential use of Augmented Reality in LIS education. Educ Inf Technol. 2016;21: 1555-1569.

[22] Chen YC. Effect of Mobile Augmented Reality on Learning Performance, Motivation, and Math Anxiety in a Math Course. J Educ Comput Res. 2019.

[23] Chen C-H, Chou Y-Y, Huang C-Y. An Augmented-Reality-Based Concept Map to Support Mobile Learning for Science. Asia-Pacific Educ Res. 2016;25: 567-578.

[24] Ruiz-Ariza A, Casuso RA, Suarez-Manzano S, Martínez-López EJ. Effect of augmented reality game Pokémon GO on cognitive performance and emotional intelligence in adolescent young. Comput Educ. 2018;116: 49-63.

[25] Garrett BM, Jackson C, Wilson B. Augmented reality m-learning to enhance nursing skills acquisition in the clinical skills laboratory. Interact Technol Smart Educ. 2015;12: 298-314.

[26] Bos AS, Herpich F, Kuhn I, Guarese RLM, Tarouco LMR, Zaro MA, et al. Educational Technology and Its Contributions in Students' Focus and Attention Regarding Augmented Reality Environments and the Use of Sensors. J Educ Comput Res. 2019; 1-17.

[27] Bos CS, Anders PL. Using Interactive Teaching and Learning Strategies to Promote Text Comprehension and Content Learning for Students with Learning Disabilities. Int J Disabil Dev Educ. 1992;39: 225-238.

[28] Hsu HJ. The Potential of Kinect as Interactive Educational Technology. 2nd Int Conf Educ Manag Technol. 2011;13: 334-338.

[29] Pho A, Dinscore A. Game-Based Learning Overview and Definition. Tips Trends Instr Technol Commitee. 2015; 15.
[30] Tobar-Muñoz H, Baldiris S, Fabregat R. Augmented Reality Game-Based Learning: Enriching Students' Experience During Reading Comprehension Activities. J Educ Comput Res. 2017;55: 901-936.

[31] Schoor C, Narciss S, Körndle H. Regulation During Cooperative and Collaborative Learning: A Theory-Based Review of Terms and Concepts. Educ Psychol. 2015;50: 97-119.

[32] Nokes-Malach TJ, Richey JE, Gadgil S. When Is It Better to Learn Together? Insights from Research on Collaborative Learning. Educ Psychol Rev. 2015;27: 645-656.

[33] Gadgil S, Nokes-Malach TJ. Overcoming Collaborative Inhibition through Error Correction: A Classroom Experiment. Appl Cogn Psychol. 2012;26: 410-420.

[34] Mollaei F, Rahnama H. Experiential Education Contributing to Language Learning. Int J Humanit Soc Sci. 2012;2: 268279.

[35] Hoover JD. Experiential learning: conceptualization and definition. Simulations, Games Exp lLearning Tech. 1974;1: 31-35.

[36] Huang TC. Seeing creativity in an augmented experiential learning environment. Univers Access Inf Soc. 2019;18: 301-313.

[37] Boud D, Miller N. Synthesising traditions and identifying theme in learning from experience. Working with experience : animating learning. 1996. 